\title{
Antagonistic effect of bacteriocin from Bacillus subtilis against food-borne pathogens
}

Syeda Nidra Hussain ${ }^{1 *}$, Muhammad Ashraf ${ }^{1}$, Hina Hanif ${ }^{1}$ and Muhammad Jamil ${ }^{2}$

1. Institute of Microbiology, University of Agriculture, Faisalabad-Pakistan

2. Arid Zone Research Centre (AZRC, PARC), Dera Ismail Khan-29050-Pakistan

*Corresponding author's email: nidrahussain@ gmail.com

Citation

Syeda Nidra Hussain, Muhammad Ashraf, Hina Hanif and Muhammad Jamil. Antagonistic effect of bacteriocin from Bacillus subtilis against food-borne pathogens. Pure and Applied Biology. Vol. 6, Issue 2, pp585-594. http://dx.doi.org/10.19045/bspab.2017.60060

Received: $10 / 01 / 2017$

Revised: 10/04/2017

Accepted: 17/04/2017

Online First: 19/04/2017

\section{Abstract}

Preservation of food items through natural and biological methods has become a norm in order to prevent huge financial losses that may be incurred as a result of contamination of raw foods and/or food products. Biological preservation methods help avert the chances of food born ailments thus ensuring the fulfillment of ever-increasing global food requirements. Growing skepticism among the customers in recent years regarding food safety and preservatives used in food industry has fetched remarkable consideration to the use of Bacillus bacteriocin in food processing as well as human health care. Bacillus subtilis was isolated from soil samples for determination of its microscopic and biochemical characteristics. The proteinaceous antimicrobial compounds were extracted through ammonium sulfate precipitation method. The bacteriocin was partially purified through SDS-PAGE; optimization of bacteriocin at different $\mathrm{pH}$ levels, heating temperatures and storage conditions was performed. Indicator strains were procured from CMS, UAF, Faisalabad. The antimicrobial assays of extracted bacteriocin were determined on Mueller-Hinton media through agar well diffusion method. The extracted bacteriocin showed comparatively better antibacterial activity against indicator Staphylococcus aureus followed by E. coli and Salmonella. Maximum activity was observed at $\mathrm{pH} 7$, heating temperature $37^{\circ} \mathrm{C}$ and storage $4^{\circ} \mathrm{C}$, comparatively higher activity against Gram positive bacteria was noticed.

Keywords: Biological preservation; Economic losses; Antimicrobial compounds; Optimization

\section{Introduction}

The economy of food processing units has been hit hard by the emergence of noxious pathogens in food stuffs. Loss of customer trust in food industries has resulted in health scares as a direct consequence to consumption of spoiled or contaminated food. Despite advances in food preservation technologies, and heterogeneity in food processing and raw materials, the smartness of microbes has enabled them to evade food safety measures with growing ease, causing food spoilage, which is one of the leading concerns for the food industry in present 
times [1, 2]. Estimations reveal that more than 200 lethal diseases are transmitted through food spoiled by microbes [3]. Campylobacter, Yersinia, Staphylococcus, Escherichia coli, Salmonella and Listeria are considered the major bacterial foodborne microbes these days [4]. Serious threats modeled by antibiotic-resistant food borne bacteria and fungi have increased the urgency for use of substitute therapeutics. Antimicrobial peptides (AMPs) are regarded as highly promising therapeutic antimicrobial compounds [5]. Principally microbes compete for limited space and nutrients in their particular type of environments, which is why they produce special type of compounds including proteins, bioactive peptides, antibiotics and bacteriocin [6]. Bacteriocin is ribosomally synthesized bioactive peptide comprising about 30-60 amino acids produced by both Gram negative and Gram positive bacteria. These are usually, but not always, effective against most closely related strains of the producer strains $[7,8]$.

Bacillus species are outstanding producers of antimicrobial compounds such as peptides, antibiotics and bacteriocin. Bacteriocin production from Bacillus is considered as second most important production after Lactic Acid bacteria (LAB). They not only produce ample masses of bacteriocin, which is ribosomally synthesized, but also some non-ribosomally produced peptides which are bacteriocin-like inhibitory-substances (BLIS), genetically non-characterized peptides. So Bacilli are prolific in producing true bacteriocins and BLIS as well $[9,10]$. The bacteriocins from Bacilli have a great potential preserving application in many food compounds like in dairy foods such as milk and cheese [11, [12]. Bacteriocin performs either bactericidal or bacteriostatic activity. The diversity in the performance and the decision as to which action will be performed is affected by too many physical factors such as quantity of extracted bacteriocins, the methods of purification of extracted bacteriocins and the physiochemical properties of target cells, which are mainly considered sensitive [13].

The Bacteriocin of Bacillus subtilis has been anticipated as an auspicious alternative of the prevailing antibiotics for the treatment of food-borne diseases for it is low-priced as well as non-hazardous nature vis-à-vis human and animal health [14].

Certain readings have assessed the therapeutic effectiveness of bacteriocins in the handling of animal and human diseases caused through food spoilage because of the resistance shown by resilient microbes to conventional antibiotics. One of the advantages of using bacteriocin in food industries is their productions at reasonably lower cost, which makes the bacteriocin an excellent candidate for antimicrobial compound and also an effective growth promoter in farm and industrial environments. The proteinaceous nature infers a putative degrading action in the gastric and intestinal tracts of animals and human beings, signifying their use as accepted preservers in foods [7]. Keenly observing the dreadful harms of food handling units and their frightening influences on human health, the present study has been defined. To extract bacteriocin from Bacillus subtilis isolated from soil sources and evaluate the antagonistic effect of bacteriocin in different food degrading bacteria.

\section{Materials and methods}

Collection and isolation of Bacillus subtilis from soil

A total of 30 samples (approximately $10 \mathrm{~g}$ from each site) were collected after removing upper $10 \mathrm{~cm}$ of litter leaf from different areas of Faisalabad using clean, dry and sterile polythene bags along with sterile spatula. All the samples were immediately 
transferred to laboratory. For further processing of samples and isolation of bacteria these were stored at $4^{\circ} \mathrm{C}$ [15].

\section{Inoculation and incubation}

About 5 gram of soil from each sample was mixed with sterile water homogenized and heated at $80^{\circ} \mathrm{C}$ and allowed to stand for $1 \mathrm{~h}$ at room temperature. A volume $0.5 \mathrm{ml}$ of this suspension was inoculated into nutrient broth and incubated for 48 hours. Microbial growth observed by turbidity and aliquots was inoculated onto nutrient agar plate and was incubated at $37^{\circ} \mathrm{C}$ for 24 hours [16].

\section{Purification of bacterial colonies}

Purification was done using streak plate method by transferring colonies from Nutrient agar plates to other Nutrient agar plates until pure colonies were obtained.

\section{Identification of isolates}

The purified streaks of bacteria were presumptively identified by cultural characteristics such as color, texture shape and size of colonies. Morphological characteristics were noticed after Gram staining, spore staining and acid fast staining. The isolates were run through couple of biochemical tests. Catalase test, Methyl-Red test, Indole production, VogesProskauer, Starch hydrolysis and sugar fermentation tests were executed and the isolated organisms from the sample were screened on the basis of their morphological and biochemical characteristics as described in Bergey's Manual of systematic bacteriology [17].

Extraction and partial purification of bacteriocin

Due to their proteinaceous nature, bacteriocin was concentrated through the application of salting-out methods, being ammonium sulfate the most frequently used salt [18]. The solid salt was added to the distilled water slowly until the desired saturation percentage of ammonium sulfate was reached. A 36-h-old culture of the bacteriocinogenic $B$. subtilis strain was centrifuged at $8000 \mathrm{rpm}$ for $25 \mathrm{~min}$ at $4^{\circ} \mathrm{C}$. The peptidic fraction was precipitated from the cell-free supernatant with $40 \%$ saturated ammonium sulfate. The suspension was agitated with magnetic stirrer and incubated overnight at $4^{\circ} \mathrm{C}$. Salted-out proteins were further precipitated by centrifugation at $15000 \mathrm{rpm}$ for 20 minutes. Collected pellets were dissolved in a small volume of $10 \mathrm{mM}$ phosphate buffer ( $\mathrm{pH}$ 7.0) or distilled water. The bacteriocin was partially purified by sodium dodecyl sulfate polyacrylamide gel electrophoresis (SDS-PAGE).

\section{Stability of isolated bacteriocins}

Stability as well as antimicrobial potential of isolated bacteriocins were checked at different (3, 5, 7 and 9) $\mathrm{pH}$ levels, heating temperatures $\left(27^{\circ} \mathrm{C}, 37^{\circ} \mathrm{C}, 60{ }^{\circ} \mathrm{C}\right.$, and $80^{\circ} \mathrm{C}$ for $40 \mathrm{~min}$ ) and different storage temperatures $\left(-20^{\circ} \mathrm{C}, 4^{\circ} \mathrm{C}\right.$ and $\left.37^{\circ} \mathrm{C}\right)$.

\section{Pathogenic bacterial strains}

The cultures of pathogenic strains (Staphylococcus aureus, E. coli and Salmonella enteritidis) were obtained from stock culture of the Department of Clinical, Medicine and surgery, Agriculture University, Faisalabad. Cultures used in this study were transferred twice in to the blood agar medium before use.

\section{Determination of antibacterial assay}

The antibacterial activity of bacteriocin was detected against Escherichia coli, Salmonella enteritidis and Staphylococcus aureus by agar well diffusion method. Bacteriocin $(25 \mu \mathrm{l})$ treated at different storage temperatures, thermal conditions and $\mathrm{pH}$ values were added to $6 \mathrm{~mm}$ wells on Mueller-Hinton agar plates. Mueller-Hinton plates were spread with $100 \mu \mathrm{l}$ suspension of each indicator strain containing 2 x 108 $\mathrm{cfu} / \mathrm{ml}$ [19]. The plates were incubated for 24 hours at specific temperature according to indicator strains used. The diameters of zone of inhibition were measured using vernier caliper. 


\section{Statistical analysis}

Data was analyzed by applying Standard Error (Mean \pm SE) and analysis of variance (ANOVA) under completely randomized design.

\section{Results}

The genus Bacillus is basically a heterogeneous group of microbes belonging to Gram positive species of bacteria. These are endospore-forming Gram positive rodshaped aerobes including extremophiles and mesophies. These are characterized by catalase production. The Bacilli have colonized diversified environments due to their ability of withstanding even harsh environments assisted by formation of resistant endospores [20].

In the present investigation, Bacillus subtilis was isolated from soil appeared as yellowish white colonies with spreading type of growth. Round and irregular colonies with diameter of 2-4 mm, Circular form and Flat elevation were observed on Nutrient agar plates. Gram staining showed purple color rods arranged separately and in chains. Culture was stored in nutrient broth at $-20^{\circ} \mathrm{C}$ with $10 \% \quad(\mathrm{v} / \mathrm{v})$ glycerol addition. The bacterium was identified on the basis of morphological and biochemical characteristics given in Table 1. Bacteriocin extracted from nutrient broth culture of Bacillus subtilis was stored in pellet form at $4^{\circ} \mathrm{C}$ in PBS [26]. SDS-PAGE gave the molecular weight of extracted bacteriocin which was in the range of 3-6KDa [9].
The antimicrobial activity of extracted bacteriocin against food degrading microbes was determined by agar well diffusion method on Mueller-Hinton medium through measuring the diameters of zones inhibited by microbes (Table 2, 3 and 4) in $\mathrm{mm}$ by vernier calipers [21]. The antagonistic activity in arbitrary units per $\mathrm{ml}(\mathrm{Au} / \mathrm{ml})$ as a measure of bacteriocin production was calculated (Table 5, 6 and 7) as described by Bhuvaneswari and his co-workers [22].

Results indicated that bacteriocin extracted from Bacillus subtilis showed maximum zone of inhibition against Staphylococcus aureus followed by E. coli and Salmonella enteritidis [22]. Bacteriocin showed maximum activity at $\mathrm{pH}$ 7. Partial reduction in activity was observed with shift of $\mathrm{pH}$ from neutral to alkalinity and acidity. The production of bacteriocin increased with increase in temperature but at $80^{\circ} \mathrm{C}$, there was an abrupt decline in activity. The activity of bacteriocin was maximum when stored at $4^{\circ} \mathrm{C}$. A slightly reduced yet significant activity was observed at $-20^{\circ} \mathrm{C}$ suggesting its role as a preservative even at chilling temperatures.

Statistical analysis showed that there was a significant difference in means of zone of inhibition produced by bacteriocin against different food- spoiling microbes at different levels of $\mathrm{pH}$, heating temperatures and storage conditions.

Table 1. Morphological and biochemical characteristics of isolated bacteria

\begin{tabular}{|l|l|l|l|l|l|l|l|l|l|}
\hline S. No & $\begin{array}{l}\text { Gram } \\
\text { staining }\end{array}$ & $\begin{array}{l}\text { Catalase } \\
\text { test }\end{array}$ & Motility & $\begin{array}{l}\text { Starch } \\
\text { hydrolysis test }\end{array}$ & $\begin{array}{l}\text { Indole } \\
\text { test }\end{array}$ & MR & VP & $\begin{array}{l}\text { Glucose } \\
\text { fermentation }\end{array}$ & $\begin{array}{l}\text { Maltose } \\
\text { fermentation }\end{array}$ \\
\hline 1. & +ve rods & +ve & Motile & $\begin{array}{l}\text { +ve, zone of } \\
\text { clearance }\end{array}$ & -ve & -ve & +ve & $\begin{array}{l}\text { +ve (Gas } \\
\text { produced })\end{array}$ & $\begin{array}{l}\text { +ve (Gas } \\
\text { produced) }\end{array}$ \\
\hline
\end{tabular}


Table 2. Zone of inhibition (mm) and OD values of bacteriocin at different pH levels produced against food pathogens

\begin{tabular}{|l|l|l|l|l|}
\hline Treatment & Staphylococcus Aureus & E. coli & Salmonella enteritidis & OD at 600 nm \\
\hline $\mathbf{p H}$ & & & & \\
\hline 3 & 9.4 & 8.9 & 8.4 & 0.95 \\
\hline 5 & 9.8 & 9.4 & 9.1 & 1.31 \\
\hline 7 & 13.9 & 13.0 & 12.4 & 1.52 \\
\hline 9 & 8.8 & 8.4 & 8.2 & 0.83 \\
\hline
\end{tabular}

Table 3. Zone of inhibition $(\mathrm{mm})$ and OD values of bacteriocin at different heating temperatures produced against food pathogens

\begin{tabular}{|l|l|l|l|l|}
\hline Treatment & Staphylococcus aureus & E. coli & Salmonella enteritidis & OD at 600 nm \\
\hline Heat $\left({ }^{\mathbf{0}} \mathbf{C}\right)$ & & & & \\
\hline 27 & 10.2 & 9.8 & 8.5 & 0.95 \\
\hline 37 & 11.6 & 10.1 & 9.4 & 1.31 \\
\hline 60 & 7.1 & 6.8 & 6.2 & 1.52 \\
\hline 80 & 1.4 & 1.2 & 1.1 & 0.83 \\
\hline
\end{tabular}

Table 4. Zone of inhibition $(\mathrm{mm})$ and OD values of bacteriocin at different storage temperatures produced against food pathogens

\begin{tabular}{|l|l|l|l|l|}
\hline Treatment & $\begin{array}{l}\text { Staphylococcus } \\
\text { aureus }\end{array}$ & E. coli & $\begin{array}{l}\text { Salmonella } \\
\text { enteritidis }\end{array}$ & $\begin{array}{l}\text { OD at 600 } \\
\mathbf{n m}\end{array}$ \\
\hline Storage temperature $\left.\mathbf{(}^{\mathbf{0}} \mathbf{C}\right)$ & & & & \\
\hline 37 & 11.2 & 9.6 & 8.1 & 0.95 \\
\hline 4 & 11.6 & 10.1 & 9.4 & 1.31 \\
\hline-20 & 10.1 & 9.1 & 7.1 & 1.52 \\
\hline
\end{tabular}

\section{Discussions}

Massive illnesses caused by food pathogens and a growing consumer refusal for the foods have urged scientists to look for novel antimicrobials to reduce food-borne health scares. The purpose of this study was to isolate bacteriocin producing Bacillus subtilis locally from soil source and to screen their bacteriocin as natural bio preservative and antimicrobial agent against Gram positive, Gram negative bacteria which produce food spoilage. Bacillus subtilis isolated from different soil samples were characterized and subjected to study the antimicrobial and food preserving activity of their bacteriocin.

Studies suggest that Bacillus species are outstanding producers of antimicrobial compounds such as peptides, antibiotics and bacteriocin. Bacteriocin production from Bacillus is considered as second most important production after Lactic acid bacteria [23]. Basically bacteriocins are polypeptides synthesized ribosomally produced by different microorganisms which belong to the eubacteria taxonomic tree [24]. Bacteriocin was isolated in little amounts due to their adsorption to cell surface. These were isolated by precipitation with ammonium sulfate according to Sambrook and co-workers [18]. This method recovered only a small portion of bacteriocin present in broth due to absorption to cell surface [25]. The Pellets collected were stored at $4^{\circ} \mathrm{C}$ in PBS [26]. The bacteriocin was partially purified and molecular weight was determined through SDS-PAGE. Previously, Nivedita with co-scientists extracted and purified Bacillus subtilis bacteriocin by gel exclusion and estimated molecular weights by SDS-PAGE. They 
found that activity units of bacteriocin increase with each step of purification [27].

Bacteriocin extracted from Bacillus subtilis exhibits remarkable action at wide ranges of $\mathrm{pH}$, nutrients, heating temperatures, enzymes and storage conditions. Bacteriocin optimized at different independent parameters showed variation in activity units produced in zones inhibited which suggested that with increase in bacteriocin production $(\mathrm{Au} / \mathrm{ml})$, the diameter of zone of inhibition gets widened [28]. Production of bacteriocin and maintenance is normally affected by diverse environmental influences such as distinctive atmospheric growth conditions, ultrasound shock and nutrient depletion on bacteriocin adsorption from cell [29].

The spectrum of inhibition was different for each bacteria used as indicator strains. The results indicated that Staphylococcus aureus was most sensitive to bacteriocin extracted from Bacillus subtilis followed by E. coli and Salmonella enteritidis (Figure 1, 2, 3). Recently potential antagonistic effects of Bacteriocins of Bacillus subtilis BMPO1 were determined which showed maximum activity against Staphylococcus aureus followed by E. coli [22].

Studies conducted before clearly indicated that bacteriocin isolated from Bacillus bacteria shows remarkable inhibitory activities against Gram positive, Gram negative and food spoiling Fungi [30]. The maximum inhibition of Staphylococcus aureus signifies the fact the bacteriocin is effective against the most closely related strain of the producer strain.

The variations of sensitivity observed against different microbes are due to specific genetic coding of target strains and characteristics of bacteriocins treated at different independent variables. Nisin was the first finest studied illustrative of the Lantibiotics finding special applications in the inhibition effect of late-blowing of cheese by hindering the development of spores Clostridium and was used in selected pasteurized food products [8].

Sutyak reported that subtilocin produced by Bacillus subtilis 22 isolated from fermented Chinese soybeans showed greater potential of antibacterial activity against food-borne resistant pathogens like Staphylococcus aureus, Salmonella typhimurium, Listeria monocytogenes and other deadly bacterial and fungal disease causing microbes [31].

The results of critical trial of statistical analysis indicated that there was significant difference between means of zones inhibited by bacteriocin optimized at different levels of $\mathrm{pH}$ and heating temperature. With shift of $\mathrm{pH}$ from acidic to neutral, the production and activity of bacteriocin increased but from neutral towards alkalinity, partial reduction of activity was noticed. Yet the unique property of bacteriocin of Bacillus subtilis of tolerating wide $\mathrm{pH}$ range places it as potential bio preservatives of acidic, neutral and alkaline foods [32].

Bacteriocin showed maximum activity when stored at $4^{\circ} \mathrm{C}$ and a slight reduction of activity was seen on $37^{\circ} \mathrm{C}$ and $-20^{\circ} \mathrm{C}$ (Figure 3 ). Scientists through experimental results suggested its use as natural preservatives of foods processed even in chilled conditions [26].

The activity of bacteriocin was found good even at $27^{\circ} \mathrm{C}$ heating suggesting its role as preservatives of foods stored at room temperatures. With certain increase in temperature, the production of bacteriocin declined and an abrupt change of activity was seen for further increase in temperature from $60^{\circ} \mathrm{C}$ to $80^{\circ} \mathrm{C}$ (Figure 2). Previously bacteriocin from $8 \mathrm{~A}$ strain of Bacillus species was purified and scientists concluded that this bioactive antimicrobial compound was stable at $55^{\circ} \mathrm{C}$ but lost its activity at $87^{\circ} \mathrm{C}[16]$.

Bacteriocin extracted from B. subtilis holds optimistic repute being used as bio preservative of food owing to all the 
necessary characteristics which prevent spoilage process. Thus preservation of food stuffs by either natural or microbiological strategies can be regarded as acceptable approach to lessen the occurrence of food borne ailments, resolving fiscal losses due to spoilage of raw food items with microbes, and develop better food supplies exactly according to the needs of rising world population [33].

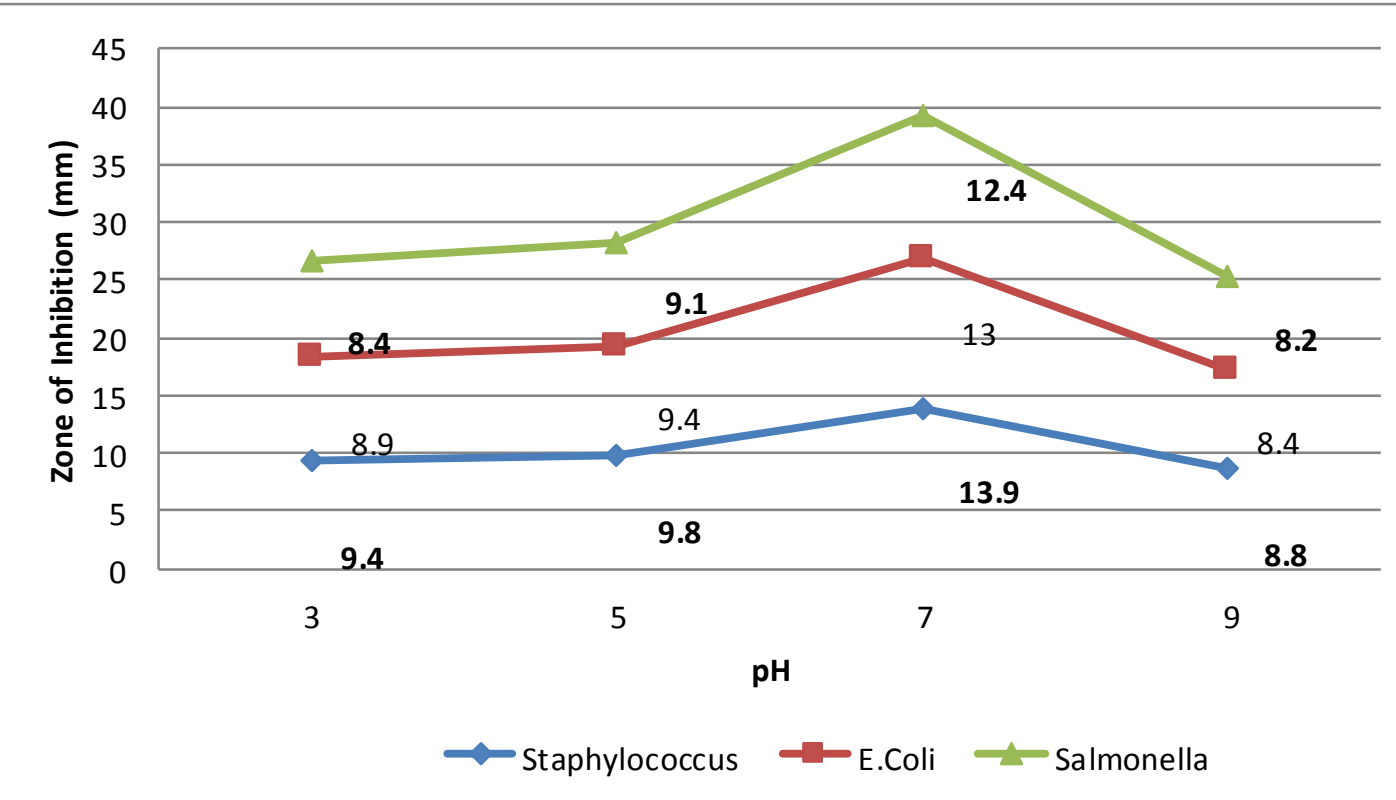

Figure 1. Comparison of antibacterial effects of bacteriocin against food pathogens at different pH levels

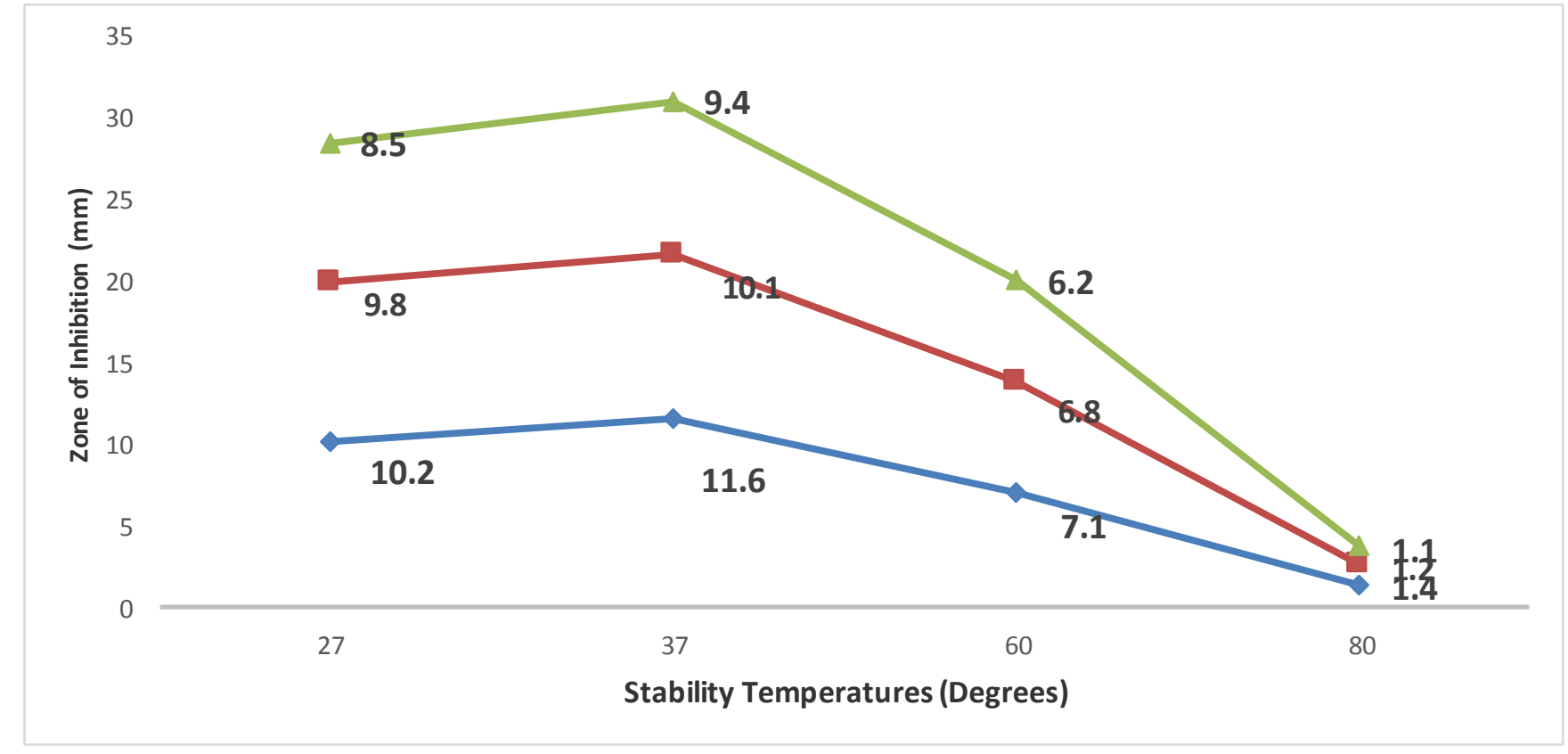

Figure 2. Comparisons of antibacterial effects of bacteriocin against pathogens at different heating temperature 


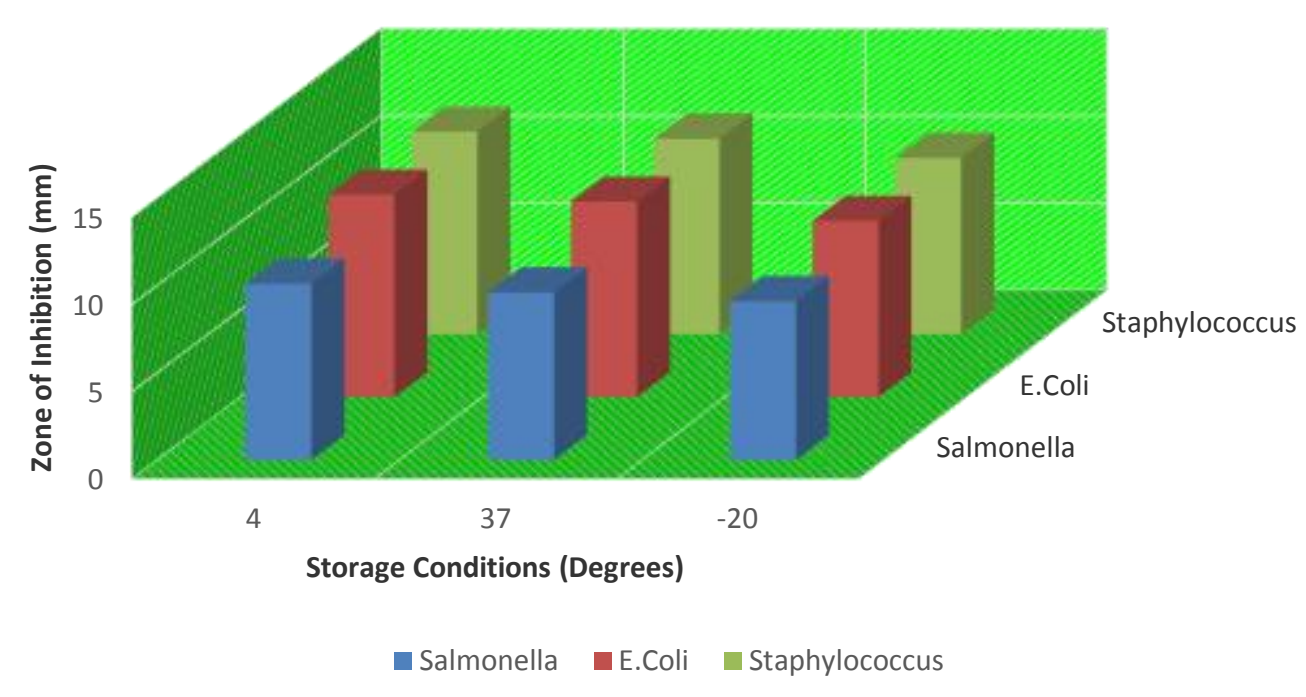

Figure 3. Comparisons of antibacterial effects of bacteriocin against pathogens at different storage temperatures

\section{Conclusion}

Bacteriocin extracted from Bacillus subtilis exhibited remarkable antibacterial activity. Maximum activity was exhibited against Gram positive bacteria (Staphylococcus aureus) followed by Gram negative bacteria (E. coli and Salmonella enteritidis). The Highest activity of bacteriocin was observed at $\mathrm{pH} 7$, heating $37^{\circ} \mathrm{C}$ and storage $4^{\circ} \mathrm{C}$. These results aptly show that bacteriocin extracted from Bacillus subtilis is good at inhibiting growth of many pathogenic microbes so they can be safely used as natural preservatives for foods and as substitute of conventional antibiotics in therapeutics.

\section{Authors' contributions}

Conceived and designed the experiments: SN Hussain \& M Ashraf, Performed the experiment: SN Hussain, Analyzed the data: SN Hussain, Contributed reagents/materials/ analysis tools: M Ashraf, M Jamil \& H Hanif, Wrote the paper: SN Hussain.

\section{Acknowledgement}

All the necessary equipment, media and ingredients required for the accomplishment of this research work were funded by postgraduate laboratory of Institute of Microbiology, University of Agriculture, Faisalabad, Pakistan.

\section{References}

1. Lone GR, Lars R, Maria BB, Jesper T \& Allan B (2002). Food spoilage_ interactions between food spoilage bacteria. The Int J Food Microbiol 78: 79-97.

2. Gram L, Ravn L, Rasch M, Bruhn JB, Christensen AB \& Givskov M (2002). Food spoilage - interactions between food spoilage bacteria. The Int J Food Microbiol 78: 79-97.

3. Bryan FL (1982). Diseases transmitted by foods-Atlanta. Centers for Disease Control, US.

4. Schlundt J (2002). New directions in food borne disease prevention. The Int $J$ Food Microbiol 78:3-17.

5. Baruzzi F, Quintieri L, Morea M \& Caputo L (2011). Antimicrobial compounds produced by Bacillus spp. and applications in food. Science against Microbial Pathogens: 
Communicating Current Research and Technological Advances. Mendez Vilas, Foramtex research center publishers, Spain 2: 1102-1111.

6. Heng NCK, Wescombe PA, Burton JP, Jack RW \& Tagg JR (2007). Bacteriocins Eco Evo 45: 92.

7. Riley MA \& Wertz JE (2002) Bacteriocin diversity: ecological and evolutionary perspectives. Biochem 84: 357-364.

8. Baby J, Berlina D, Vimalin H \& Justin R (2013). Bacteriocins from Bacillus subtilis as a novel drug against diabetic foot ulcer bacterial pathogens. Asian Pac J Trop biomed 3: 942-946.

9. Abriouel H, Franz CM, Omar NB \& Gálvez A (2011). Diversity and applications of Bacillus bacteriocins. FEMS Microbiol Rev 35: 201-232.

10. Moore T, Globa L, Barbaree J, Vodyanoy V \& Sorokulova I (2013). Antagonistic activity of Bacillus bacteria against food-borne pathogens. JPH 12: 1-14.

11. Sharma N \& Gautam N (2007). Use of bacteriocin as potential bio preservative in milk, cheese and apple juice. J Beverage \& Food World 34: 44-47.

12. Sharma N, Attri A \& Gautam N (2009). Purification and characterization of bacteriocin like substance produced from Bacillus lentus with perspective of a new biopreservative for food preservation. Food Sci \& Tech Int 52: 191-199.

13. Cintas LM, Casaus MP, Herranz C, Nes IF \& Hernández PE (2001). Review: bacteriocins of lactic acid bacteria. Food Sci \& Technol Int 7: 281-305.

14. Xie J, Zhang R, Shang C \& Guo (2009). Isolation and characterization of a bacteriocin produced by an isolated Bacillus subtilis LFB112 that exhibits antimicrobial activity against domestic animal pathogens. African $J$ Biotechnol 8:20.

15. Amin M, Rakhisi Z \& Ahmady AZ (2015). Isolation and Identification of Bacillus Species From Soil and Evaluation of Their Antibacterial Properties. Avicenna $J$ Clinical Microbiol \& Infect 2: 1.

16. Bizani D \& Brandelli A (2002). Characterization of a bacteriocin produced by a newly isolated Bacillus sp. strain 8A. J Appl Microbiol 93: 512-519.

17. Krieg N (1984). Bergey's Manual of Systematic Bacteriology. New York: ASM publishers.

18. Sambrook J, Fritsch EF \& Maniatis T (1989). Molecular cloning: A Laboratory Manual. $5^{\text {th }}$ ed. Vol 1. New York: ASM Press.

19. Iqbal A (1989) Production, purification and characterization of bacteriocins from indigenous clinical Staphylococci. Ph.D Thesis Deptt of Microbiol Uni of Karachi, Pakistan.

20. Nicholson WL (2002). Roles of Bacillus endospores in the environment. Cellular and Molecular Life Sci 9: 410-416.

21. Ashok V, Gomashe, AA, Sharma \& Mamta A (2014). Screening and Evaluation of Antibacterial Activity of Bacteriocin Producing Lab against some Selected Bacteria Causing Food Spoilage. Int J Curr Microbiol \& Appl Sci 3 : 658-665

22. Bhuvaneswari S, Madhavan S \& Panneerselvam A (2015). Optimization of bacteriocin production by Bacillus subtilis BMPO1 isolated from Solanum trilobatum L. Int J Curr Microbiol and Appl Sci 3: 617-626.

23. Gebhardt K, Chimana JS \& Muller J (2002). Screening for biologically active metabolites with endosymbiotic 
Bacilli isolated from arthropods. FEMS Microbiol Lett 217: 199-205.

24. Sanlibaba P \& Uymaz B (2014) Characteristics of bacteriocin and its history. Food Technol 4: 18.

25. Kaiser A \& Montville TJ (1996). Purification of bacteriocin, bavaricin $\mathrm{MN}$ and characterization of mode of action against Listeria Monocytogenesscott A cells and lipid vesicles. Appl \& Environ Microbiol 62: 4529-4535.

26. Ansari A, Aman A, Siddiqui NN, Iqbal S \& Qader SA (2012). Bacteriocin (BAC-IB17): screening, isolation and production from Bacillus subtilis KIBGE IB-17. Pak J Pharm Sci25: 195-201.

27. Nivedita S, Kapoor R, Gautam N \& Kumari R. (2011). Purification and characterization of bacteriocin produced by Bacillus subtilis R75 isolated from fermented chunks of mung bean (Phaseolus radiatus). Food Technol \& Biotech 49: 169.

28. Bhaskar N, Sudeepa ES, Rashmi HN \& Selvi AT (2007). Partial purification and characterization of protease of Bacillus proteolyticus CFR3001 isolated from fish processing waste and its antibacterial activities. Bioresource Technol 98: 2758-2764.
29. Settanni L, Valmorri S, Suzzi G \& Corsetti A (2008). The role of environmental factors and medium composition on bacteriocin like inhibitory substances (BLIS) production by Enterococcus mundtii strains. Food Microbiol 25:722- 728.

30. Naclerio G, Ricca E, Sacco M \& De Felice M (1993). Antimicrobial activity of a newly identified bacteriocin of Bacillus cereus. Appl and Environ Microbiol 59: 4313-4316.

31. Sutyak KE, Wirawan RE, Aroutcheva AA \& Chikindas ML (2008). Isolation of the Bacillus subtilis antimicrobial peptide subtilosin from the dairy product-derived Bacillus amyloliquefaciens. J Appl Microbiol 104: 1067-1074.

32. Martirani L, Arcamonti MV, Naclerio G $\&$ Felic MD (2002). Purification and partial characterization of bacillocin 490, a novel bacteriocin produced by a thermophilic strain of Bacillus licheniformis. Microbial Cell Factories 1:1-5.

33. Galvez A, Lucas LR, Abrioue A, Valdivia E \& Omar NB (2008). Application of bacteriocins in foodborne pathogenic and spoilage bacteria. Critical Revi in Biotechnol 28: $125-152$. 